\title{
Dimensions of Phubbing Among Moslem Adolescents in Revolution Industry 4.0: Perspective Mental Health
}

\section{Iredho Fani Reza}

Faculty Of Psychology UIN Raden Fatah, Palembang Indonesia, iredhofanireza@gmail.com

\begin{abstract}
In the era industrial revolution 4.0 the impact of science and technology has a positive impact and some have a negative impact. The purpose of this research is to reveal the dimensions of phone snubbing among Muslim teenagers in the mental health perspective. This research is a type of qualitative research with a grounded theory design. Respondents in this study amounted to 97 people who were among moslem adolescents as undergraduate students at a state Islamic university in Indonesia which was determined using purposive sampling technique. The collection method uses questionnaires, interviews and observations. The main analysis method uses coding technique technique which consists of open coding, axial coding and selective coding. The results of this study conclude that the dimensions of phone snubbing among moslem adolescents include, first, ignore others and switch to gadgets, second, dependency on gadgets, third, social disconnectedness.
\end{abstract}

Keywords:Dimensions of Phubbing, Revolution Industry 4.0, MoslemAdolescents, Mental Health

\section{Introduction}

The $21^{\text {st }}$ century has entered the 4.0 industrial revolution marked by four main characteristics, namely vertical networking of smart, production systems, horizontal integration via a new generation of global value chain networks, through-engineering across the entire value chain and the impact of exponential technologies(Deloitte, 2015). In the 4.0 industrial revolution all aspects of human life have been touched by science and technology. Both in the fields of government, work, education and other fields. Science and technology become a symbol and necessity that exists in aspects of human life. The development of science and technology in the 4.0 industry revolution one of which focuses on internet connection in every aspect of life(Crnjac, Veža, \& Banduka, 2017). One of the applicable forms of the development of science and technology is the use of mobile phones that were originally only for calling, sending and receiving messages. It has been turned into a smart phone or android which is not only physically changing, but has increased its function.

Cellular phones have provided a new color in human life in the days of the industrial revolution 4.0. Everything human needs are easily obtained with the help of a smart phone.However, the development of cellular phones in the 4.0 industrial revolution era. The tendency not only has a 
positive impact on human life. But there is a negative impact on human life. Where one of them is disrupting social relations with fellow human beings. To the extent that a new slogan appears for mobile phone users who tend to experience negative impacts from cellular phones, namely phubbing (phone snubbing).

The word 'Phubbing', was created to describe a unique $21^{\text {st }}$ century phenomenon that ignores the person in front of you who supports your telephone. John Mescall and Adrian Mills strategized in early 2012 with Susan Butler, Publisher and Editor from Macquarie Dictionary recruiting teams that created the word phubbing. In 2016, Phubbing was accepted in the Oxford English Dictionary(McCann, 2018).

The word phubbing or abbreviation for phone snubbing is still relatively new. From 2012 to 2018, only five years have been found. However, through the discovery of this word provides many new discourses on the phenomenon that occurred in the 21st century. From the preliminary study that researchers conducted on students in one of the Islamic state universities in Indonesia. That shows that the phubbing phenomenon is almost a sight that has become accustomed to students. When talking with the other person or at a forum. There are students who ignore their interlocutors and prefer to open a cellular phone.

Research by Karadağ, et all(2015)shows that the most important determinants of phubbing behavior are cellphones, SMS, social media and internet addiction.It is undeniable that smart phones today are a necessity in every human life, if they can be used correctly. however, if its use interferes with aspects of human life. One of them is the aspect of social relations. then cellular phones can also bring negative things in human life. as the results of Chotpitayasunondh and Douglas (2018) revealed that increasing phubbing has a significant and negative influence on the quality of perceived communication and relationship satisfaction.

In the mental health perspective, according to World Health Organization (WHO) (2014)that someone who is declared mentally healthy is having a complete physical, mental and social condition and not just the absence of illness or weakness. So if you examine it, someone who is doing phubbing, has experienced an indication of mental illness? This is because one aspect of being mentally healthy based on the definition of WHO is that someone who can establish good social relationships. But not for individuals who tend to do phubbing when interacting with fellow humans.

Nazir dan Pişkin(2016)phubbing is the action of ignoring others during social events and hours by using smart phones, whether it is checking Facebook, using whats app or using other chatting applications. Phubbing can be seen anywhere during human beings daily activities, i.e. during meals, meetings, lectures, or social gatherings with friends and family. Phubbers (those who phub) often neglect and ignore the importance of maintaining and/or developing relationships by not communicating with others.

However, it cannot directly accuse someone who interacts with fellow human beings. At that time he held a cellphone or had to see a cell phone directly accused of phubbing. must be known in advance what are the dimensions of someone who can be said to have done phubbing. So based on the existing phenomenon and various expert opinions. So this study aims to find the dimensions of phubbing among moslem adolescents in revolution industry 4.0 : perspective mental health.

\section{Method}

This research is a type of qualitative research with a grounded theory design. Grounded theory is a qualitative strategy in which the researcher derives a general, abstract theory of a process, action, or interaction grounded in the views of participants in a study(J W Creswell, 2013).Subjects in this study were undergraduate students at one of the Indonesian Islamic State Universities who participated as many as 97 people (26 Men and 71 Women). Subjects in this study were determined using purposive sampling technique(Tongco, 2007). In the purposive sampling technique, a 
researcher determines his own criteria or characteristics in detail who is the subject / research informant, based on predetermined criteria(Reza, 2016).

The consideration of determining the subjects in this study were students who were Muslim teenagers, students active in one of the Islamic universities in Indonesia, men and women, willing to become research respondents. The instruments in this study used a Combination Type Questionnaire (Fields and Options) which revealed questions about phubbing(Reza, 2016).The procedure for preparing questionnaire questions in this study refers tofive Ws and an $\mathrm{H}^{\prime \prime}$ of who, what, when, where, why, and how(Singer, 2008).The researcher asked several questions based on the five method questions. As well as displaying several images that indicate social situations and subject is then asked about the image.Researchers used Google Form assistance as a medium to create questionnaires and collect data.The questions in this study can be seen in table 1 .

Table 1. Questions in the Phubbing Questionnaire for this study

\begin{tabular}{|c|c|c|c|}
\hline No & Question & Figure & Response \\
\hline 1 & Gender & - & Multiple Choice \\
\hline 2 & $\begin{array}{l}\text { Do you know or have heard the word } \\
\text { Phubbing? }\end{array}$ & - & Multiple Choice \\
\hline 3 & What do you think is phubbing? & - & Paragraph \\
\hline 4 & $\begin{array}{l}\text { What do you think is happening in } \\
\text { Figure 1? tell me! }\end{array}$ & $\begin{array}{c}\text { Figure } 1 \\
\text { Source: (Afifiyah, 2018) }\end{array}$ & Paragraph \\
\hline 5 & $\begin{array}{l}\text { What do you think is happening in } \\
\text { Figure 2? tell me! }\end{array}$ & $\begin{array}{c}\text { Figure } 2 \\
\text { Source: (Sitwell, 2017) }\end{array}$ & Paragraph \\
\hline 6 & $\begin{array}{l}\text { Tell us about your experience in detail } \\
\text { when in a situation like in picture } 2 ?\end{array}$ & $\begin{array}{c}\text { Figure } 2 \\
\text { Source: (Sitwell, 2017) }\end{array}$ & Paragraph \\
\hline 7 & $\begin{array}{l}\text { What do you experience when in the } \\
\text { situation in Figure 2? }\end{array}$ & $\begin{array}{c}\text { Figure } 2 \\
\text { Source: (Sitwell, 2017) }\end{array}$ & Paragraph \\
\hline 8 & $\begin{array}{l}\text { How much intensity do you experience } \\
\text { in picture } 2 \text { ? }\end{array}$ & $\begin{array}{c}\text { Figure } 2 \\
\text { Source: (Sitwell, 2017) }\end{array}$ & Linear Scale \\
\hline 9 & $\begin{array}{l}\text { What do you think is happening in } \\
\text { figure } 3 / 4 \text { ? Tell me! }\end{array}$ & $\begin{array}{c}\text { Figure } 3 \\
\text { Source: (Sanusi, 2018) } \\
\text { Figure } 4 \\
\text { Source: (Alpha Resource } \\
\text { Center, 2017) } \\
\end{array}$ & Paragraph \\
\hline 10 & $\begin{array}{l}\text { Tell us about your experience in detail } \\
\text { when in a situation like in figure } 3 / 4 \text { ? }\end{array}$ & $\begin{array}{c}\text { Figure } 3 \\
\text { Source: (Sanusi, 2018) } \\
\text { Figure } 4 \\
\text { Source: (Alpha Resource } \\
\text { Center, 2017) }\end{array}$ & Paragraph \\
\hline 11 & $\begin{array}{l}\text { What do you experience when in a } \\
\text { situation in figure } 3 / 4 \text { ? }\end{array}$ & $\begin{array}{c}\text { Figure } 3 \\
\text { Source: (Sanusi, 2018) } \\
\text { Figure } 4 \\
\text { Source: (Alpha Resource } \\
\text { Center, 2017) }\end{array}$ & Paragraph \\
\hline 12 & $\begin{array}{l}\text { How much intensity do you experience } \\
\text { the situation in figure } 3 / 4 \text { ? }\end{array}$ & $\begin{array}{c}\text { Figure } 3 \\
\text { Source: (Sanusi, 2018) } \\
\text { Figure } 4 \\
\text { Source: (Alpha Resource } \\
\text { Center, 2017) }\end{array}$ & Linear Scale \\
\hline
\end{tabular}


Data analysis technique used is coding technique which consists of three stages of analysis, open coding, axial coding and selective coding(John W Creswell, 2012). The data analysis phase begins with the researcher collecting data from the google form questionnaire into table form with the help of an excel program. Then the researchers selected unique themes from the results of the questionnaire and grouped them into one theme. The next stage the researcher connects the relationship between the theme and draws conclusions into the theme of the findings. To test the validity of qualitative data, researchers used triangulation techniques and tested qualitative data reliability using check transcripts and cross-check codes (J W Creswell, 2013).This study took place from May to September which consisted of preparation processes, data collection, data analysis and preparation of research reports.

\section{Results and Discussion}

\section{Results}

Findings in this study. Described based on the results of the analysis of the coding of the questionnaire in this study. So that the theme categories are obtained according to their respective discussions. The researcher explained in various sub-discussions that were the findings of this study. As follows:

\section{a. Description of Research Subject}

Subjects in this study were undergraduate students at one of the Indonesian Islamic State Universities who participated as many as 97 people (26 Men and 71 Women).The percentage distribution of the subject is seen inchart 1 .

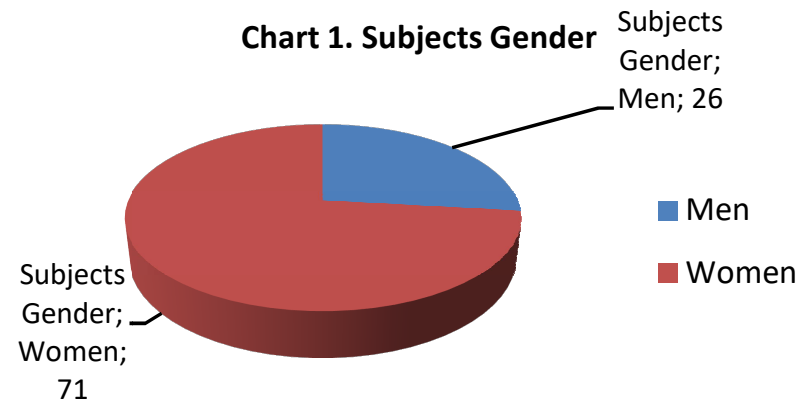

\section{b. Findings Of Research Themes}

From the data collection of this study, researchers found several main themes. Explanation of each theme as follows:

\section{Subject Knowledge About Phubbing Words}

This theme is to see how the level of knowledge of all subjects is about the word phubbing (phone snubbing). Does the subject know about the word phubbing. From the results of processing subject knowledge data about the word phubbing can be seen inchart 2 .

Chart 2. Subject Knowledge About Phubbing Words

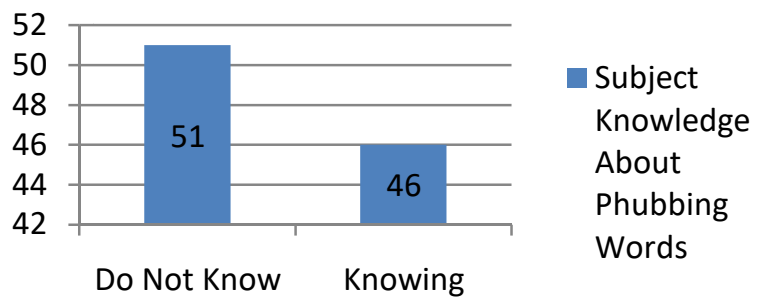


From the diagram of column 1. it can be seen that out of 97 research subjects, there were 51 subjects who did not know what the word phubbing was and 46 other subjects knew the word phubbing. From the results of the grouping of answer categories the subject who knows about the word phubbing is 46 subjects. Several themes were obtained in an effort to formulate the word phubbing in this study. Can be seen in table 2 .

Table2. Subject Opinion About the Meaning of Phubbing (Phone Snubbing)

\begin{tabular}{ccc}
\hline No & $\begin{array}{c}\text { Theme: Subject Opinion } \\
\text { About the meaning of Phubbing }\end{array}$ & Response \\
\hline 1 & Ostracize someone & 4 \\
\hline 2 & Ignore Others & 37 \\
\hline 3 & Insulting Others & 1 \\
\hline 4 & Mental Illness & 2 \\
\hline 5 & Gadget Dependency & 2 \\
\hline Total Subject Response & 46 \\
\hline
\end{tabular}

Based on the results of data processing about subject knowledge of the word phubbing. That there are five themes that are successfully classified to formulate the definition of the word phubbing based on the results of this empirical research. The formulation of the word phubbing definition can be seen in the second sub of the findings, namely understanding the meaning of phubbing (phone snubbing).

\section{Understanding The Meaning Of Phubbing (Phone Snubbing)}

This second theme is to find out the meaning of phubing (phone snubbing) through empirical data. By knowing the meaning of empirical phubbing, it can provide insight to everyone what is meant by the phubbing. Here are some search results about the definition of the word phubbing according to experts including:

- David and Roberts (2017)the word phubbing is a combination of two words, namely "phone" and "snubbing" to be phone snubbing.

- McCann (2018)the word "Phubbing", coined to describe the uniquely 21st century phenomenon of ignoring the person in front of you in favour of your phone.

- Nazir dan Pişkin(2016)phubbing is the action of ignoring others during social events and hours by using smart phones, whether it is checking Facebook, using whats app or using other chatting applications.

- Karadag et al (2015) phubbing can be described as an individual looking at his or her mobile phone during a conversation with other individuals, dealing with the mobile phone and escaping from interpersonal communication.

- Davey et al (2018) “Phubbing" phenomenon, in the frequent use of a smartphone, describes the habit of snubbing someone in favor of a mobile phone.

- Cizmeci (2017)Phubbing is the act when mobile devices lead people to ignore the ones beside them, and so cut the interpersonal communication.

Based on the results of the data obtained from the questionnaire that there are five themes that are classified to formulate the definition of phubbing (phone snubbing) reviewed from the perspective of mental health and psychological studies. The five themes include isolating someone, ignoring others, insulting others, mental illness, gadget addiction. 
The five themes about the word phubbing, researchers relate to the opinions of previous experts. So that in the perspective of mental health and the study of psychology, the meaning of the word phubbing which stands for phone snubbing is defined as ignore behavior when communicating with others by switching to gadgets (cellphones, smart phones, laptops and others) just to check messages, see social media and just open gadgets without any purpose.

\section{Mental Health and Mental Illness}

This third theme provides an overview of phubbing in a mental health perspective. Based on the results of data coding analysis from this research questionnaire. A unique theme arises from the results of the answers to research subjects. That phubbing is understood as a mental illness, some even understand it as someone who has a mental disorder. As revealed by the subject person:Phubbing is a mental disorder in someone(Subject 31); Phubing is mental illness (subject 42).

In an effort to reveal whether someone indicated phubbing was considered to have experienced a mental illness. Where people who do phubbing are called phubber. Then it is necessary to conduct further research and more in-depth studies on mental health perspective phubbing. In this study, researchers found the possibility of phubber could be said to have indicated mental illness.

When referring to the opinion of the World Health Organization (WHO) (2014) about the definition of mental health itself is as a state of well-being in which every individual realizes his or her own potential, can cope with the normal stresses of life, can work productively and fruitfully, and is able to make a contribution to her or his community. As well as mental health itself has dimensions in which the positive dimension of mental health is stressed in WHO's definition of health as contained in its constitution: "Health is a state of complete physical, mental and social infirmity".

So the initial indication is if it refers to the definition of WHO mental health. So it is important to know whether phubbing affects the dimensions of human mental health that exist. Such as complete physical, mental and social weakness. If three dimensions of mental health are disrupted, it can be said that phubbing is a factor that can cause a person to experience mental illness. Of course these findings need to be reviewed and more focused and in-depth research studies.

\section{Ignore Others}

This theme is one of the unique themes and mostly comes from the analysis of questionnaires filled by research subjects. Ignore other people having behavioral indicators such as:don't want to start talking to other people and choose a gadget, can't become a good listener and choose a gadget, not responding to other people's talks and choosing gadgets.

\section{Dependency Gadgets}

This theme is one of the unique themes derived from the analysis of questionnaires filled by research subjects. Dependence on gadgets that have behavioral indicators such as:cannot be without gadgets, spend more time for gadgets.

\section{Social Disconnectedness}

This theme is one of the unique themes derived from the analysis of questionnaires filled by research subjects. Social disconnectednessthat have behavioral indicators such as:not interested in social activities and more interested in gadgets, avoiding social interaction situations and preferring gadgets.

\section{Discussion}

Based on the results of the analysis of answers to questionnaires by research subjects. There are several unique themes and are the main findings in this study. there are two main theme theme categories that deserve to be discussed further and answer this research question. First, what is the dimension of phubbing. Second, how to do it in a mental health perspective. 
From the analysis of the research questionnaire data, there are five themes that indicate the dimensions of phubbing. These five have been through coding analysis consisting of open coding, axial coding and selective coding. Detailed explanation as contained in table 3.

Tabel 3. Coding Tema Dimensi Phubbing

\begin{tabular}{lll}
\hline \multicolumn{1}{c}{ Axial Coding } & \multicolumn{1}{c}{ Selective Coding } & \multicolumn{1}{c}{ Interpretation } \\
\hline Ignore Others & Ignore Others & Ignore Others and Switch to Gadgets \\
\hline Dependency Gadgets & Dependency Gadgets & Dependency Gadgets \\
\hline Social Disconnectedness & Social Disconnectedness & Social Disconnectedness \\
\hline Mental Illness & & \\
\hline
\end{tabular}

Based on the axial coding process of the research questionnaire data. Phubbing dimension theme categories are four themes as shown in table 3. After going through selective coding stages, three themes are indicated as phubbing dimensions. The next step the researcher conducted a review of the relevant theories so as to bring up a conclusion of the interpretation of the two coding processes of research data.

\section{Chart 3. Dimensions of Phubbing}

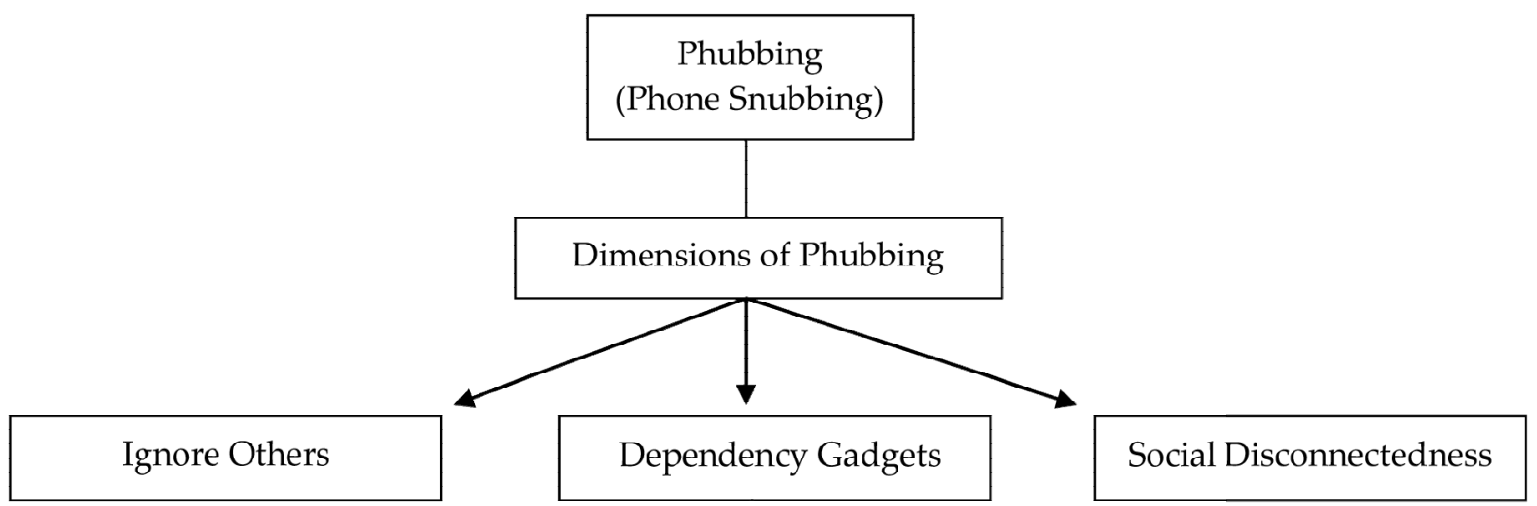

While one mental illness theme is grouped into the impact of the phubbing itself.The first dimension of ignore others is phubbing behavior where when interacting with other people, whether in the form of communication between two or more people and when interacting, someone starts playing gadgets without a clear purpose.Ignore other people having behavioral indicators such as:don't want to start talking to other people and choose a gadget, can't become a good listener and choose a gadget, not responding to other people's talks and choosing gadgets.These findings, in line with some of the findings of previous studies; McCann (2018), Nazir \& Piskin (2016), Cizmeci(2017).

The second dimension ofdependency gadgets is the behavior of phubbing where it doesn't feel like staying long without playing gadgets.Dependence on gadgets that have behavioral indicators such as:cannot be without gadgets, spend more time for gadgets.These findings, in line with some of the findings of previous studies.Someone phubbing can cause an increased need for attention and results in individuals who are attached to social media in the hope of regaining a sense of inclusion(David \& Roberts, 2017).Determinants of phubbing behavior are mobile phone, SMS, social media and internet addictions(Karadağ et al., 2015).

The third dimension of social disconectedness is the behaviour of phubbing where a person is not interested in social activities and avoids it.Social disconnectedness that have behavioral indicators such as:not interested in social activities and more interested in gadgets, avoiding social interaction situations and preferring gadgets.These findings, in line with some of the findings of previous studies.The impact of phubbing can affect significantly and negatively affected communication quality and relationship satisfaction (Chotpitayasunondh \& Douglas, 2018).Phubbing is an important factor in modern communication that warrants further investigation(Chotpitayasunondh \& Douglas, 2016). 
Phubbing relationship with mental health can be seen from the impact of phubbing behavior. Previous research shows that phubbing behavior can cause a person's mental disorder. As with Balta's research, et all (2018), phubbing causes fear of loss, the use of Instagram that is problematic, character anxiety, and neuroticism.Chotpitayasunondh \& Douglas(2018)Phubbing can threaten our basic human needs.

Chart 4.Phubbing Relationship With Mental Health

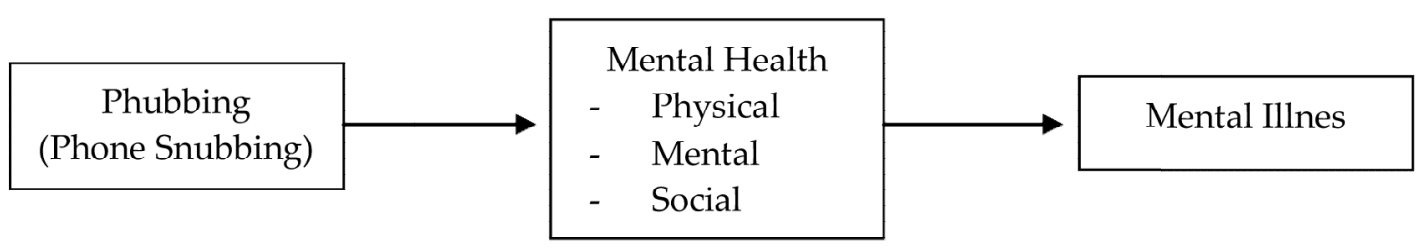

Based on an explanation of the relationship between phubbing and mental health. Emphasized on the impact caused by acting on one's mentality. This needs further study and research.

\section{Conclusions}

This study concludes that discussion has three dimensions: first, ignore others and switches to gadgets, second, dependency on gadgets, third, social disconnectedness. In the perspective of mental health, phubbing has an impact on a person's mental health. This is because the effects of phubbing can interfere with the stability of the mental health dimension: complete physical, mental and social infirmity. In the end someone who is phubbing can experience mental illness.

The results of this study become the basis for further research on phubbing themes in various perspectives. The relationship between phubbing behavioral and mental health. More empirical studies are needed. Through the results of this study can provide a view to everyone about the dimensions of phubbing. By knowing these dimensions, practically one can avoid phubbing behavior. The next researcher is expected to provide a view to researching phubbing from various perspectives as well as its relationship to aspects of human life.

\section{Acknowledgments}

Thank you to my family for their prayers and support, so that this research can be completed. Thanks also to the academic community of the Faculty of Psychology, State Islamic University Raden Fatah Palembang who also provided support so that this research can be presented at IcomethNCP2018.

\section{References}

Afifiyah, S. (2018). Waktu Keluarga Bebas Phubbing, Ini Empat Tips. Retrieved October 6, 2018, from https://www.tagar.id/waktu-keluarga-bebas-phubbing-ini-empat-tips

Alpha Resource Center. (2017). Phubbing [cell phone snubbing] vs. Being Present in Your Relationships - Alpha Resource Center. Retrieved October 6, 2018, from https://www.alpharesourcecenter.com/marriage-success/phubbing-cell-phone-snubbing-vsbeing-present-in-your-relationships/

Balta, S., Emirtekin, E., Kircaburun, K., \& Griffiths, M. D. (2018). Neuroticism, Trait Fear of Missing Out, and Phubbing: The Mediating Role of State Fear of Missing Out and Problematic Instagram Use. International Journal of Mental Health and Addiction. https://doi.org/10.1007/s11469-018-9959-8

Chotpitayasunondh, V., \& Douglas, K. M. (2016). How "phubbing" becomes the norm: The antecedents and consequences of snubbing via smartphone. Computers in Human Behavior. https://doi.org/10.1016/j.chb.2016.05.018 
Chotpitayasunondh, V., \& Douglas, K. M. (2018). The effects of "phubbing" on social interaction. Journal of Applied Social Psychology, 48(6), 304-316. https://doi.org/10.1111/jasp.12506

CIZMECI, E. (2017). DISCONNECTED, THOUGH SATISFIED: PPHUBBING BEHAVIOR AND RELATIONSHIP SATISFACTION. THE TURKISH ONLINE JOURNAL OF DESIGN, ART AND COMMUNICATION. https://doi.org/10.7456/10702100/018

Creswell, J. W. (2012). Educational research: Planning, conducting, and evaluating quantitative and qualitative research. Educational Research (Vol. 4). https://doi.org/10.1017/CBO9781107415324.004

Creswell, J. W. (2013). Research Design: Qualitative, Quantitative, and Mixed Methods Approaches. Research design Qualitative quantitative and mixed methods approaches. https://doi.org/10.1007/s13398-0140173-7.2

Crnjac, M., Veža, I., \& Banduka, N. (2017). From concept to the introduction of industry 4.0. International Journal of Industrial Engineering and Management, 8(1), 21-30.

Davey, S., Davey, A., Raghav, S. K., Singh, J. V, Singh, N., Blachnio, A., \& Przepiórkaa, A. (2018). Predictors and consequences of \&quot;Phubbing\&quot; among adolescents and youth in India: An impact evaluation study. Journal of Family $\mathcal{E}$ Community Medicine, 25(1), 35-42. https://doi.org/10.4103/jfcm.JFCM_71_17

David, M. E., \& Roberts, J. A. (2017). Phubbed and Alone: Phone Snubbing, Social Exclusion, and Attachment to Social Media. Journal of the Association for Consumer Research. https://doi.org/10.1086/690940

Deloitte. (2015). Industry 4.0. Challenges and solutions for the digital transformation and use of exponential technologies. Deloitte AG. Zurich.

Karadağ, E., Tosuntaş, Ş. B., Erzen, E., Duru, P., Bostan, N., Şahin, B. M., ... Babadağ, B. (2015). Determinants of phubbing, which is the sum of many virtual addictions: A structural equation model. Journal of Behavioral Addictions, 4(2), 60-74. https://doi.org/10.1556/2006.4.2015.005

McCann. (2018). Phubbing - a word is born I McCANN Australia. Retrieved October 9, 2018, from https://mccann.com.au/project/phubbing-a-word-is-born/

Nazir, T., \& Pişkin, M. (2016). Phubbing: A Technological Invasion Which Connected the World But Disconnected Humans. The International Journal of Indian Psychology, 3(4), 2348-5396. Retrieved from http://www.ijip.in

Reza, I. F. (2016). Metodologi Penelitian Psikologir: Kuantitatif, Kualitatif dan Kombinasi. Palembang: Noer Fikri Offset.

Sanusi, T. (2018). Phubbing Can Ruin Your Relationship, So Here's How To Tell Your Partner To Stop. Retrieved October 6, 2018, from https://www.elitedaily.com/p/phubbing-can-ruin-yourrelationship-so-heres-how-to-tell-your-partner-to-stop-8654143

Singer, J. B. (2008). Five $W s$ and an Hø: Digital Challenges in Newspaper Newsrooms and Boardrooms. International Journal on Media Management, 10(3), 122-129. https://doi.org/10.1080/14241270802262468

Sitwell, K. L. (2017). The anti-social art of phubbing | LinkedIn. Retrieved October 6, 2018, from https://www.linkedin.com/pulse/anti-social-art-phubbing-kamila-laura-sitwell/

Tongco, M. D. C. (2007). Purposive sampling as a tool for informant selection. Ethnobotany Research and Applications, 5, 147-158. https://doi.org/10.17348/era.5.0.147-158

World Health Organization. (2014). WHO । Mental health: a state of well-being. Retrieved October 9, 2018, from http://www.who.int/features/factfiles/mental_health/en/ 